\title{
Teacher's Engagement in the Social and Emotional Guidance of Elementary School Students
}

\author{
Jessie Koh-Sing Tnay
}

PhD Student, Universiti Malaysia Sarawak, Malaysia, 16010071 @ siswa.unimas.my

\section{Shahren Ahmad Zaidi Adruce}

Prof., Institute of Borneo Studies, Universiti Malaysia Sarawak, Malaysia, azshahren@unimas.my

\section{Evan Lau}

Assoc. Prof., Faculty of Economics and Business, Universiti Malaysia Sarawak, Malaysia,lphevan@unimas.my

\section{Hiram Ting}

Assoc. Prof., Faculty of Hospitality and Tourism Management, UCSI University, Malaysia, hiramting@ucsiuniversity.edu.my

\section{Chuo Yew Ting}

PhD Student, Universiti Malaysia Sarawak, Malaysia, 16010072@siswa.unimas.my

\section{Mukvinder Kaur Sandhu}

Chief Operating Officer, Faculty of Hospitality and Tourism Management, UCSI

University, Malaysia, mukvinders@ucsiuniversity.edu.my

The present study aims to explore the criteria which motivate and prevent teachers from engaging in the social and emotional guidance of rural elementary school students in Malaysia. Face-to-face in-depth interviews were conducted with 25 teachers using purposive sampling technique and they are from 15 rural primary schools within the Sarawak state of Malaysia. While emerging themes for motivations are teachers' task perception, colleagues' support, students' family support, and teachers' professionalization, barriers include burdensome workloads and time constraints. The results are discussed to provide insights for policymakers and educational administrators on the development of a whole-school approach that aims to promote the social and emotional wellbeing of rural students in a developing country.

Keywords: social and emotional guidance, teacher engagement, rural school, Malaysia, elementary school students

Citation: Tnay, J. K. S., Adruce, S. A. Z., Lau, E., Ting, H., Ting, C. Y., \& Sandhu, M. K. (2020). Teacher's Engagement in the Social and Emotional Guidance of Elementary School Students. International Journal of Instruction, 13(3), 827-844. https://doi.org/10.29333/iji.2020.13355a 


\section{INTRODUCTION}

The social and emotional wellbeing (SEW) of students has a substantial impact on the development of their physical, mental, and learning outcomes (Durlak et al., 2011; World Health Organization, 2003). Durlak et al., (2011) conducted a meta-analysis on interventions that aimed to enhance the SEW of students and found that the incorporation of evidence based social and emotional learning (SEL) programming into standard educational practises led to significant improvement in the students' social and emotional skills, attitudes, behaviour, and academic performances. A 4-year longitudinal study conducted by Croninger and Lee (2001) revealed that teachers' support and guidance reduced the students' likelihood to drop out of school by half. All of this evidence supports the initiatives and efforts of promoting the balanced and full development of students by integrating social and emotional learning with academic learning in schools. The World Health Organization (2003) has been advocating for the creation of a conducive school environment that promotes the social and emotional wellbeing of students. It has become a common trend for policy makers, authorities, scholars, and practitioners around the globe to advocate for the integration of social and emotional guidance with intellectual development in schools (Drefs, 2003; Durlak et al., 2011; Hui, 2000, 2002; Kidger et al., 2001). Amongst the ASEAN countries, Hong Kong and China actively promote the SEW of students in schools (Hui \& Lo, 1997). Recently, the National Education Philosophy in Malaysia also emphasizes the balanced and harmonious development of students, which includes addressing their intellectual, spiritual, emotional, and physical needs (Ministry of Education, Malaysia, 2018).

Although the importance of students' SEW has been emphasized in education policies across nations, some have reported difficulties integrating social and emotional learning into the existing education systems due to competing demands and limited resources (Jacobs \& Struyf, 2015; Yuen et al., 2007). For instance, Yuen et al., (2007) suggested that one of the reasons Hong Kong primary school teachers were less involved in social and emotional guiding tasks was the time constraints they faced. Likewise, Malaysian teachers also report similar challenges, with the additional burden of perceived redundant clerical work ("Teachers: Teaching no longer a passion," 2018). In addition to the burdensome clerical work, teachers' enthusiasm for ensuring the students' wellbeing is weakened when they are assigned to rural schools, which often lack basic infrastructure, and resources, particularly in the often hard-to-reach outskirts of the Sarawak State of Malaysia ("Manyin: Education ecosystem," 2018). According to the Minister of Education, Science, and Technological Research, Sarawak has 428 and 721 rural schools that still do not have treated water supply and proper road access, let alone Internet connectivity ("Manyin: Education ecosystem," 2018). These constraints are attributed to the large geographical area of the state, the fragmented rural population, and the lack of funds. As a result, the state government faces difficulty placing a sufficient number of qualified teachers to rural schools, because most prefer to teach in urban schools with sufficient resources ("Teachers' woes in rural Sarawak," 2010). Teachers in rural Sarawak are found to have been struggling with transportation and communication barriers that separate them from their families, which indirectly causes them to lose focus and affect their morale over time. Consequently, the decrease in 
teacher to student ratio further impedes the ability of rural teachers to address the social and emotional needs of their students through personalised interactions ("STU welcomes," 2018). Many scholars also point out that the magnitude of SEW problems is often greater amongst rural students than their urban counterparts due to their lower socio-economic status (Ahmad et al., 2015; Kasmini et al., 1993).

Furthermore, students in primary school are entering an important stage of their development that can either build or destruct their confidence and personality development (Eccles et al., 1993). When their needs were unattended, it will lead to host patterns of undesirable behaviours (Weinten, 2007). This situation happens especially when they have been left behind by their parents. Hence, with the intention of promoting SEW in rural primary school students, a study that identifies the factors affecting the engagement of teachers in the social and emotional guidance of rural primary school students is warranted. Unlike in developed countries, where educational programmes often have a significant integrated SEW aspect, countries like Malaysia have a long way to go in imbedding SEW in its formal education structure. Moreover, most past studies focused on teachers' motivation towards academic teaching (Richardson et al., 2014) and were conducted in developed or western countries (Roth, 2014; Thomson \& Palermo, 2018) with little implications on SEW. In light of the importance to find ways to empower teachers in this effort, the present study would prove useful to policy makers, authorities, and education administrators to gain insights into the issues and hence formulate efficient strategies to enhance the facilitators and alleviate the barriers to the development of the SEW of students.

\section{LITERATURE REVIEW}

\section{Theories on Teachers' Motivation}

There are three prominent theories adapted to empirically test the motivation of teachers, namely the expectancy-value theory of achievement motivation (Green, 2002; Thomson \& Palermo, 2018; Wigfield \& Eccles, 2000), achievement goal theory (Butler, 2007; Wang et al. 2017), and self-determination theory (Eyal \& Roth, 2011; Gagné \& Deci, 2005; Roth, 2014). Besides, several scholars have integrated different cognitivemotivational theories with the intention to develop a better understanding of complex human behaviours (Neves de Jesus \& Lens, 2005; Turner et al., 2009). For instance, Neves de Jesus \& Lens (2005) integrated the learned helplessness/attribution reformulation (Abramson et al., 1978; Miller \& Norman, 1979), achievement goal theory (Maehr \& Zusho, 2009), self-efficacy theory (Bandura, 1977), and intrinsic motivation theory (Deci \& Ryan, 1985) to understand how teachers' professional engagement and education would impact their motivation. It is worth studying how all of these factors affect the motivation of teachers to provide social and emotional guidance.

\section{Engagement in Social and Emotional Guidance of Rural Primary School Students}

Studies are also done to evaluate SEW intervention in classroom settings (Durlak et al., 2011). Notably, most of these interventions are administered by teachers (53\%), while others are a mixture of university researchers, consultants, and parents. However, these studies only examine the impact of the intervention on predetermined outcomes, such as 
social and emotional skills as well as academic performance, without paying much attention to the role and involvement of teachers in the development of the SEW of students during the usual school days. Few studies exploring the role and involvement of teachers in students' social and emotional guidance have been conducted in Belgium (Jacobs \& Struyf, 2015) and Hong Kong (Lam \& Hui, 2010), thus providing limited generalizability to other countries with different education systems and different sociodemographic characteristics of their populations. Notwithstanding, none of these past studies focus on the factors influencing the involvement of teachers in the social and emotional guidance of the rural primary school students.

Facilitation and Barriers of Teachers' Engagement in Social and Emotional Guidance

Jacobs \& Struyf (2015) proposed and empirically tested a comprehensive model of the integrated socio-emotional guidance that aimed to explain what facilitating class teachers did to integrate social and emotional guidance in their classrooms. The study surveyed 3,336 Flemish secondary school teachers and revealed that teachers' task perception, professionalization, teacher communication, clear structures and procedures, and principal support were the significant facilitators. On the other hand, Hui (2002) conducted a study that triangulated the qualitative and quantitative approaches amongst Hong Kong teachers about their perception of a whole-school approach to social and emotional guidance and its implementation. The study revealed that teacher dedication, communication, and team spirit facilitated the implementation of the whole-school approach. However, an overall mismatch was discovered between the teachers' beliefs about a whole-school approach and their perceived reality. For instance, although most of the respondents had positive beliefs about the whole-school approach, most of them did not perceive that their schools had actually practiced it in reality. In particular, they did not perceive that their school promoted sufficient team spirit and communication, much less involve the teachers in policy making.

In addition, Lam \& Hui (2010) conducted semi-structured interviews with 12 Hong Kong secondary school teachers to explore: (1) teachers' perception of education, guidance, and counselling; (2) ownership of responsibility in the whole-school approach to guidance; (3) teachers' actual practice in guidance and counselling; (4) school support for teachers to practice guidance and counselling; and (5) constraints on teachers in relation to practising guidance and counselling. Firstly, they found that all respondents attributed the meaning of education to the whole-person development. Secondly, some respondents perceived that guidance and counselling is part of their obligation, while some did not. Such perceived ownership of responsibility was driven by their personal beliefs on education, perception of students' needs, inspiration from former teachers and colleagues, a sense of social responsibility, and school climate. Thirdly, teachers became involved in social and emotional guidance through reactive and responsive guidance, such as helping students with their study career choices and detecting and offering support for students' personal, emotional, and behavioural difficulties, without being confined to the classroom setting. Fourthly, supports and recognition given by school administrators encourage the involvement of teachers in guidance and counselling. 
Evidently, some of them were not clear about the role of school counselling team teachers.

Although the facilitating factors might have provided sufficient insights into the implementation of a whole-school approach policy, the potential barriers that would only emerge during actual practice cannot be underestimated. According to Lam \& Hui (2010), constraints reported by the respondents included lack of skills, heavy workload that led to teachers' exhaustion, and a lack of training on guidance and counselling. Adopting a whole-school approach to provide students with social and emotional guidance has been viewed by many as simply impractical, given the current constraints on teachers' time from the already overwhelming paper work and curriculum (Henderson \& Tilbury, 2004). Moreover, teachers' work becomes increasingly dependent upon the externally imposed apparatus of behavioral objectives, assessment, and accountability, leading to chronic overload and loss of opportunities to be creative and to care for their pupils (McNess et al., 2003). As a result of the challenging tasks, reforms, and expectations, it is therefore difficult for teachers to take responsibility for the social and emotional guidance of their students.

In Malaysia, burdensome workloads including assisting schools in administrative tasks, handling students' discipline, engaging in extracurricular activities, monitoring students attendance, evaluating students' homework, and meeting all the requirements of the job has led teachers to experience occupational stress, emotional exhaustion, work-family conflicts, and decreased job performance and satisfaction. (Johari et al, 2018; Misoi, 2008; Mukundan et al., 2016; Roslan et al., 2015; Shafie et al., 2017; Simbula, 2010). Hence, it is reasonable to believe that the existing burdensome workloads cause teachers to be less engaged in social and emotional guidance, as aforementioned. Nonetheless, the lack of training provided to teachers also brings them a lower sense of self-efficacy in social and emotional guidance. Such trainings are often limited to specialists such as school counsellors and school administrators only.

\section{METHOD}

\section{Study Design}

A qualitative approach was adopted to investigate the facilitators and barriers to teachers' engagement in the development of the social and emotional wellbeing of students through face-to-face in-depth interviews. Specifically, interviews among rural primary school teachers in Sarawak was administered. Prior permission to conduct this study was obtained from the Ministry of Education Malaysia to ensure that the data collection complied with the ministries' existing rules and regulations. 
Table 1

Demographic Characteristics of Respondents

\begin{tabular}{|c|c|c|c|c|c|c|c|}
\hline No. & Gender & Race & Age & $\begin{array}{l}\text { Location of } \\
\text { school }\end{array}$ & $\begin{array}{l}\text { Duration of teaching } \\
\text { service (years) }\end{array}$ & Teaching subject & $\begin{array}{l}\text { Duration of } \\
\text { interview (min) }\end{array}$ \\
\hline ID 1 & Female & Bidayuh & 33 & Serian & 12 & Science & 22 \\
\hline ID 2 & Female & Chinese & 43 & Engkilili & 22 & Malaysian Language & 15 \\
\hline ID 3 & Female & Iban & 30 & Daro & 6 & Malaysian Language & 15 \\
\hline ID 4 & Female & Chinese & 31 & Englilili & 10 & Chinese and Mathematics & 17 \\
\hline ID 5 & Male & Bidayuh & 34 & Betong & 13 & Physical Education & 15 \\
\hline ID 6 & Female & Bidayuh & 27 & Long Teran & 6 & Mathematics & 22 \\
\hline ID 7 & Male & Iban & 38 & Daro & 17 & Science & 20 \\
\hline ID 8 & Female & Chinese & 53 & Engkilili & 26 & Chinese & 15 \\
\hline ID 9 & Female & Bidayuh & 36 & Serian & 15 & Science & 20 \\
\hline ID 10 & Male & Chinese & 39 & Engkilili & 18 & Chinese, Science, Mathematic & \\
\hline ID 11 & Male & Bidayuh & 40 & Serian & 12 & Mathematics & 20 \\
\hline ID 12 & Female & Bidayuh & 50 & Serian & 23 & Malaysian Language & 20 \\
\hline ID 13 & Female & Chinese & 53 & Engkilili & 26 & Mathematics & 16 \\
\hline ID 14 & Male & Indian & 48 & Betong & 20 & Malaysian Language & 20 \\
\hline ID 15 & Female & Chinese & 29 & Engkilili & 8 & English and Mandarin & 17 \\
\hline ID 16 & Female & Bidayuh & 36 & Serian & 13 & English Language & 22 \\
\hline ID 17 & Female & Bidayuh & 40 & Serian & 19 & English Language & 25 \\
\hline ID 18 & Female & Bidayuh & 40 & Daro & 19 & Malaysian Language & 15 \\
\hline ID 19 & Female & Bidayuh & 40 & Daro & 19 & English Language & 24 \\
\hline ID 20 & Female & Iban & 36 & Betong & 15 & Malaysian Language & 23 \\
\hline ID 21 & Female & Iban & 27 & Betong & 6 & Malaysian Language & 25 \\
\hline ID 22 & Female & Bidayuh & 33 & Serian & 8 & Malaysian Language & 17 \\
\hline ID 23 & Female & Bidayuh & 35 & Serian & 10 & English Language & 19 \\
\hline ID 24 & Female & Bidayuh & 33 & Serian & 8 & English Language & 20 \\
\hline ID 25 & Female & Bidayuh & 33 & Serian & 8 & English Language & 22 \\
\hline
\end{tabular}

\section{Sample}

In order to gain insights that could represent the perspectives of rural primary school teachers in Sarawak, teachers were selected and approached purposefully from 11 rural primary schools in the southern, central, and northern zones of Sarawak. The rural primary schools in this study were schools located at a sub-district of Sarawak State of Malaysia (Sarawak Government, 2018). The names of these schools would not be disclosed so as to assure the respondents that the information given would not cause any personal or organizational ramifications.

In order to gain rich information about the factors influencing the engagement of rural primary school teachers in the development of the social and emotional wellbeing of students, purposive sampling strategy was appropriated. Selection criteria were outlined to recruit respondents who (1) were serving as regular subject teachers; (2) had a minimum teaching experience of 5 years; (3) had experience engaging in the development of the social and emotional wellbeing of students prior to the study; (4) spoke fluent English, Malay, or Chinese; and (5) were Malaysians. Respondents who were (1) assigned as counselling teachers, (2) temporary or contract-based teachers, and (3) school administrators were excluded. Nevertheless, only those who agreed with and signed the study consent form were recruited. Invitation to participate was made through 
phone calls or emails. Sample size was determined by means of data saturation. The details of the demographic characteristics of the respondents are shown in Table 1.

\section{Data Collection}

An interview manual consisting of the interview flow chart, two open-ended guiding questions, and suggested probing questions were developed to ensure the consistency of the interviews conducted by the enumerators. The guiding questions were (1) "How did you, as a teacher of a rural primary school, engage in the development of the social and emotional wellbeing of your students?" and (2) "What were the facilitators and barriers that prevented you from being engaged in the social and emotional wellbeing development of your students?" A training session comprising a briefing of the interview manual and a hands-on trial interview was conducted by the lead researcher for the enumerators prior to data collection. In addition, the enumerators were trained to transcribe the interviews verbatim and analyse the data in a consistent manner. During the actual interviews, prospective respondents were given details of the study, including the research objectives, the respondents' roles and rights as the subjects, such as their anonymity and withdrawal. All interviews were audio recorded, and field notes were taken by the enumerators. Data collection and analysis were carried out iteratively after the enumerators conducted and transcribed each interview (Creswell, 2007). Since iterations would serve as a reflexive process, it is crucial for enumerators to connect emerging insights through multiple rounds of revisiting the data along with a deepened understanding of the transcriptions (Srivastava \& Hopwood, 2009).

\section{Data Analysis}

Thematic analysis was employed, and guidance on the thematic analysis in the literature was followed (Nowell et al., 2017). Once an interview was conducted, the enumerator transcribed verbatim the audio record using a transcript template and uploaded the transcript to cloud storage on Google Drive. After that, the four enumerators conducted the analysis independently by highlighting the relevant quotes and providing codes for the quotes on the transcript. Respondents also took part in the interpretation process during which transcripts were shown to the participants to seek their validation after completion of the interview (Hammersley \& Atkinson, 2007). The transcripts were repeatedly read, and tentative themes were identified. Relevant extracts in the text were highlighted and then grouped without comment under themes. Thereafter, clusters were labelled manually according to their dominant themes, and new labels were created using the method by Park et al. (2018). Finally, extracts were paraphrased, or suitable quotations were selected to illustrate the categories. The actual words of the participants were used without correcting the grammar and vernacular phrasing. Enumerators were also encouraged to provide their reflective thoughts on the transcript. Any discrepancies on the interpretations would be discussed with the intention to achieve agreement. 


\section{FINDINGS}

\section{Facilitator 1: Self-Expectation as a Teacher}

22 respondents $(88 \%)$ mentioned that it was their responsibility to address the social and emotional needs of their students. However, two had different intrinsic motivators that drove their perceived responsibility; one mentioned sympathy, and the other indicated the importance of social and emotional wellbeing on students' academic performance. These motivators were personality traits (agreeableness, sympathy), goal achievement (perceived importance of promoting SEW of students in improving their academic performance), and attainment value (enthusiastic about the role and importance of a teacher in students' development).

"I take it personally due to my responsibility as a teacher. The sympathy towards the student gives me the courage and spirit to help them more than what I can do as a teacher. Sometimes I feel that they are my kids and I need to take good care of them." (Female, Iban ethnicity, 30 y/o, Malay teacher)

"I do not feel annoyed when dealing with problem students because it is my responsibility. Moreover, my intervention might influence the students' passing rate and also the learning. I first try to understand their backgrounds and build good relationships by having them trust me. This makes them focus and enjoy my classes." (Female, Chinese ethnicity, 30y/o, Science and Mathematics teacher)

\section{Facilitator 2: Support from Colleagues}

Most of the respondents (94\%) mentioned that support from colleagues facilitated their initiatives to address the social and emotional needs of their students. In particular, the sharing of ideas on how to address the problems amongst the colleagues was a substantial benefit.

"Colleagues are important to me, as they help me a lot when I am having problems dealing with students' issues at school. We help each other all the time." (Female, Chinese ethnicity, 43 y/o, Malay teacher)

"We always talk with each other on the problems so that we are able to exchange ideas and know what to do in order to help the students together." (Female, Bidayuh ethnicity, 27 y/o, Mathematics teacher)

\section{Facilitator 3: Support from Students' Families}

24 respondents (94\%) emphasized the importance of family support in facilitating their efforts to address the social and emotional needs of students. Supportive family members were regarded as key facilitators in achieving the social and emotional wellbeing of students.

"I cannot do it alone... but I am so lucky because the students' parents and family always support me as a teacher. Family support from the student's family is very important to get this thing done and to achieve the national philosophy that very 
much emphasizes students' social and emotional well-being. " (Male, Iban ethnicity, 38 y/o, Science teacher)

On the other hand, 11 respondents (44\%) mentioned that unsupportive family members had hindered them in their efforts to achieve the social and emotional wellbeing of students. Parents who did not show concern toward the wellbeing of their children and were unwilling to cooperate with teachers discouraged the social and emotional development of students.

"Barriers are parents who are passive and do not care about the welfare of their children." (Female, Bidayuh ethnicity, 40 y/o, Mathematics teacher)

"Lack of parental support for the development of children at home, lack of cooperation by parents in helping teachers to develop effective emotional and social development of pupils." (Female, Bidayuh ethnicity, 50 y/o, Malay teacher)

\section{Facilitator 4: Professional Development and Exposure}

One respondent stated that her exposure to different teaching methods while pursuing a higher degree improved her skills to build relationships with her students and address their social and emotional needs. We adopt the theme used by Jacobs \& Struyf (2014), referred to as professionalization, to explain this phenomenon. Specifically, the term "professionalization" refers to the teachers' preparation and training on engagement in social and emotional guidance.

"My depth of understanding teaching and learning came when I took my master in education... as I got exposed to many kinds of teaching methods that helps to build student-teacher relationship and indirectly improve my skills to address their social and emotional needs" (Female, Chinese ethnicity, 39 y/o, Chinese, Science and Mathematics teacher)

\section{Barrier 1: Burdensome Workloads}

There are many barriers the rural teachers faced that prevented them from actively engaging in the social and emotional wellbeing of their students. A prominent emerging theme related to the barriers was burdensome workloads (94\%). One respondent mentioned that an increased workload prevented her from having sufficient time with her family, which in turn diminished her intentions to address the social and emotional needs of her students.

"As a teacher, the workload always gave me a headache due to the juggling between all the lessons and the administrative tasks that has to be done on the same day. We also don't have enough time with our families due to time constraints, and this often leads to diminished focus on our students' emotional and social needs and development. (Female, Iban ethnicity, 30 y/o, Malay teacher)

Notably, two respondents mentioned that the burdensome workload was worsened with the frequent change in the curriculum and that it increased their administrative tasks without providing sufficient support. 
"I like to teach students; the only problem is too much paper work. Before the introduction of the new curriculum, we had more time to get in touch with the students." (Female, Chinese ethnicity, 53 y/o, Mathematics teacher)

"Now teachers are not just busy teaching. They also need to handle lots of paperwork. Plus, the poor Internet connection here is not helpful." Male, Indian ethnicity, 48 y/o, Malay teacher)

\section{Barrier 2: Time Constraints}

The majority of the respondents mentioned that their busy schedules hindered them from paying attention to the students' social and emotional wellbeing.

"The barriers for us what I can share is... time constraints, and we as teachers really have a packed school schedule. We teach back-to-back in the mornings and have to tend to co-curriculum activities in the afternoons, so I have no time to look after the students' social and emotional wellbeing." (Male, Iban ethnicity, $38 \mathrm{y} / \mathrm{o}$, Science teacher).

\section{DISCUSSION}

\section{Facilitators of Teachers' Engagement in Social and Emotional Guidance}

Teachers' task perception is found to have substantial impact on teachers' engagement in social and emotional guidance. This finding is consistent with that of past studies (Jacobs \& Struyf, 2015; Lam \& Hui, 2010), which found that teachers' perception of whether addressing the social and emotional needs of students is part of their responsibilities has a significant influence on their engagement in social and emotional guidance. Specifically, teachers' broad task perception serves as a facilitator (Jacobs \& Struyf, 2015). In contrast, teachers' narrow task perception of the teachers' obligation is merely confined to students' academic learning, while the social and emotional guidance should be handled by specialists such as psychologists, school counsellors, or disciplinary teachers, hinders their engagement in social and emotional guidance. Furthermore, one of the personality traits, "agreeableness," as mentioned in the fivefactor theory of personality (McCrae \& Costa, 1999), has been found to be a driver to teachers' broad task perception. Studies also reveal that personality traits influence the social entrepreneurship start-up intention (Nga \& Shamuganathan, 2010). As social entrepreneurship requires high voluntarism and broad task perception towards social needs, personality traits such as agreeableness and sympathy are crucial for individuals to develop. Similarly, as addressing social and emotional needs of students require additional resources without equivalent rewards, personality traits, particularly agreeableness, could be a strong driver for broad task perception. In addition, teachers who perceive the importance of addressing the social and emotional needs of students in improving their academic performance have driven them to develop broad task perception. This can be explained by the achievement goal theory (Maehr \& Zusho, 2009; Wang et al., 2017), which states that teachers are willing to take up any challenges (including spend more time and effort on the SEW development of students) in order to achieve the goal (improvement in academic performance and greater job satisfaction). 
In addition, teachers who are enthusiastic about their jobs (having "teacher's spirit"), will drive them to develop broad task perception. This can be explained by the expectancy-value theory of achievement motivation (Green, 2002; Thomson \& Palermo, 2018; Wigfield \& Eccles, 2000). According to the theory, the attainment value, which emphasizes the importance of a particular behaviour on one's identity (being a teacher in the context of this study), can influence teachers' task perception.

Addressing the social and emotional needs of students often requires cooperation and communication between colleagues. Respondents of this study stressed the importance of colleagues' support through the provision of advice and ideas that would facilitate their engagement in social and emotional guidance. This is also consistent with past studies (Jacobs \& Struyf, 2015; Lam \& Hui, 2010), which report that a supportive network at school is crucial for teachers' involvement in social and emotional guidance. Support amongst colleagues through sharing of ideas inevitably increases the perceived subjective norms among them and invites a conducive school climate to promote the SEW of students (Ajzen, 1991; Lam \& Hui, 2010; Martin \& Kulinna, 2004).

On another note, students' family support, especially from their parents, has a substantial impact on teachers' involvement in social and emotional guidance. Parents who are supportive inevitably enhance the effectiveness of solving the social and emotional problems of students. This finding corresponds to most of the past literature (Hui, 2002; Lapan, 2001). However, interestingly, a study by Jacobs \& Struyf (2015) found that communication with parents is not a significant contributing factor to teachers' involvement in social and emotional guidance. They argued that the variable "communication with parents" would only have a direct effect on children's learning and development but has less or no effect on the teachers' involvement in social and emotional guidance (Jacob \& Struyf, 2015). In contrast, respondents of this study expressed their helplessness when the students' parent not only failed to show support but ignored the SEW needs of their students. Such learned helplessness could have a substantial negative impact on the teachers' future engagement in social and emotional guidance (Abramson et al., 1978; Neves de Jesus \& Lens, 2005). Thus, it is imperative for school administrators to build and maintain good rapport and trust with the local community and students' family, especially their parents, which in turn could enhance the teachers' interventions on addressing the social and emotional needs of their students.

One respondent also mentioned that furthering her education had given her the opportunity to gain exposure to knowledge and skills that are required to address the social and emotional needs of students. Sufficient training would enhance the teachers' sense of self-efficacy, intention, and actual engagement in social and emotional guidance (Ajzen, 1991; Bandura, 1977; Jacobs \& Struyf, 2015). This finding corroborates past studies (Jacobs \& Struyf, 2015; Lam \& Hui, 2010). Most of the respondents in these studies mentioned that lack of skills and training had refrained them from addressing the social and emotional needs of their students effectively. Such situations, if unsolved, would result in learned helplessness and further reduce their future involvement in social and emotional guidance. For instance, some respondents in this study faced complex 
social and emotional student problems, such as incest and teen rape. They expressed helplessness when they realized that the students' family members were the sources of their social and emotional problems. Such problems are common in rural Sarawak ("Group: Sarawak incest," 2017). The respondents also expressed their feelings of helplessness in addressing students' social and emotional needs when their students fell victims to these criminal acts. They worried they would make things worse if they reported the incidents to the law enforcers. Reporting would risk the students' loss of further parental support and later being stigmatized by their peers. It is worth noting that most of the rural schools in Sarawak do not have designated counselling teachers. Thus, teachers in rural Sarawak have been urged to act as counsellors ("Rep tells teachers," 2013). This warrants the provision of training on social and emotional guidance to rural teachers, particularly in Sarawak.

\section{Barriers to Teachers' Engagement in Social and Emotional Guidance}

Most of the respondents mentioned burdensome workloads that led to exhaustion, workfamily conflicts, and time constraints, all of which prevented them from engaging in social and emotional guidance. This finding is consistent with the literature and affects teachers in different nations (Hui, 2002; Jacobs \& Struyf, 2015). Teachers are often burdened with increased clerical work due to the demand for accountability by authorities (Department of Education, United Kingdom, 2018; Ibrahim, 2018; Rashid et al., 2017; Sellen, 2016) and curriculum reform (Hui, 2002; Lam \& Hui, 2010). Past studies revealed that Malaysian teachers faced emotional exhaustion, work-family conflicts, occupational stress, and reduced performance and job satisfaction due to burdensome workloads (Johari et al., 2018; Misoi, 2008; Mukundan et al., 2016; Roslan et al., 2015; Shafie et al., 2017; Simbula, 2010). This inevitably imposes a negative impact on the teachers' engagement in social and emotional guidance.

Some countries have taken counteractive measures to reduce teachers' workloads through policy change and education reformation, so that teachers can focus on their core business of teaching and guidance (Department of Education, United Kingdom, 2018; Sellen, 2016). In Malaysia, the new government has taken the initiative to reduce the workload of teachers by terminating the auditing process by the Inspectorate and Quality Assurance Council (Ibrahim, 2018). However, the impact of such policy changes on the actual workloads of teachers is perceived to be insufficient, as some stakeholders are encouraging substantial changes, such as the abolishment of the existing primary school evaluation tests and promoting a well-rounded education, rather than the current style of education, which is exam-oriented (Shah, 2018). Such advocacy is in line with the Malaysia national education philosophy that emphasizes the balanced development of students. More detailed studies are required to evaluate the impact of policy changes on the actual burden, job performance, psychological wellbeing, job satisfaction, and engagement in social and emotional guidance amongst teachers in Malaysia. 


\section{CONCLUSION}

All in all, policy makers and education authorities should focus on instilling and inculcating the spirit of cooperation in teachers, as this can motivate their broad task perception and subsequently greater engagement in social and emotional guidance. At the same time, policy makers and education authorities should strive to reduce or eliminate redundant clerical work in order to enable teachers to dedicate their time to address the social and emotional needs of students. In contrast to Belgium and Hong Kong, the whole-school approach remains new to Malaysian educators. Even though the SEW of students has been emphasized in the Malaysian education philosophy, there have been no policies, clear guidelines, or instructions given to teachers on their engagement in the development of SEW of students as in Belgium and Hong Kong. In order to promote the SEW of students effectively, Malaysian policy makers could consider formulating policies or guidelines in consultation with teachers together with other stakeholders (school administrators, counsellors, psychologists, relevant expertise, parents, community leaders, and non-governmental organizations) with the intention of orchestrating their efforts and producing synergistic effects. Such guidelines could also reduce unnecessary conflicts due to misunderstanding among the stakeholders, which would offset the hard work put forth by all of them.

It is also imperative to provide training on social and emotional guidance among teachers who serve in rural schools in Sarawak. Much needs to be done to address the development of resources, especially in rural schools. The fact that all students of Sarawak should have equal access to resources including well-trained and professional teachers makes it even more important for policy makers to re-consider and reform teacher education. To achieve a developed status, states and countries must initiate education reform and indeed the development of SEW in students immediately. These novel and simple changes can potentially revolutionize Malaysia's educational system, and schools must look into rigorous teacher programs that train teachers to deal with the development of students' SEW. School systems must also be improved to make school environments more equitable. With this, teachers must have the opportunities to focus on the basics, such as individualised counselling and guidance. Benchmarking with the best education systems in the world is necessary for such changes to be made.

Although the findings of this study provide valuable insights, it has limited generalizability, as it employed the qualitative inquiry approach. Moreover, the respondents were teachers who serve in the primary schools of rural Sarawak, and the sample did not include representatives from Peninsular Malaysia or Sabah. Nonetheless, the teachers who were willing to participate in this study due to personal relationship with the lead researcher might indicate particular and similar dispositions to the other Malaysian teachers. This study has contributed to the understanding of the facilitators and barriers affecting the engagement of teachers in the social and emotional guidance of rural students in the Sarawak State of Malaysia. Future studies could empirically test the factors identified by using the quantitative approach with the intention of generalizing the findings. Moreover, future investigations should also take students' perspectives into consideration, including their characteristics and experience and 
triangulate the data with that of the teachers in order to provide a more holistic understanding of SEW and its implementation.

\section{ACKNOWLEDGEMENT}

The authors thank the anonymous referees and the editor for their helpful comments and suggestions on an earlier draft. Financial support from the Universiti Malaysia Sarawak [Dayak Chair grant No: F01/DRC/1631/2017] is greatly appreciated.

\section{REFERENCES}

Abramson, L. Y., Seligman, M. E., \& Teasdale, J. D. (1978). Learned helplessness in humans: Critique and reformulation. Journal of Abnormal Psychology, 87(1), 49-74.

Ahmad, N., Muhd Yusoff, F., Ratnasingam, S., Mohamed, F., Nasir, N. H., Mohd Sallehuddin, S., \& Aris, T. (2015). Trends and factors associated with mental health problems among children and adolescents in Malaysia. International Journal of Culture and Mental Health, 8(2), 125-136.

Ajzen, I. (1991). The theory of planned behavior. Organizational Behavior and Human Decision Processes, 50(2), 179-211.

Bandura, A. (1977). Self-efficacy: toward a unifying theory of behavioral change. Psychological Review, 84(2), 191-215.

Butler, R. (2007). Teachers' achievement goal orientations and associations with teachers' help seeking: Examination of a novel approach to teacher motivation. Journal of Educational Psychology, 99(2), 241-252.

Creswell J. W. (2007). Qualitative inquiry \& research design: Choosing among five approaches. Thousand Oaks, California: Sage Publications, Inc.

Croninger, R. G., \& Lee, V. E. (2001). Social capital and dropping out of high school: Benefits to at-risk students of teachers' support and guidance. Teachers college record 103(4), 548-581

Deci, E., \& Ryan, R. M. (1985). Intrinsic motivation and self-determination in human behavior. Springer Science \& Business Media.

Department of Education, United Kingdom. (2018, November 5). Reducing teacher workload [Policy paper]. Retrieved from https://www.gov.uk/government/publications/reducing-teachers-workload/reducingteachers-workload.

Drefs, M. (2003). Developmental considerations for school-wide comprehensive guidance and counseling programs. Guidance \& Counseling, 18(4), 153-161.

Durlak, J. A., Weissberg, R. P., Dymnicki, A. B., Taylor, R. D., \& Schellinger, K. B. (2011). The impact of enhancing students' social and emotional learning: A meta-analysis of school-based universal interventions. Child Development, 82(1), 405432. 
Eccles, J. S., Midgley, C., Wigfield, A., Buchanan, C. M., Reuman, D., Flanagan, C., \& Mac Iver, D. (1993). Development during adolescence: The impact of stageenvironment fit on young adolescents' experiences in schools and in families. American Psychologist, 48(2), 90.

Eyal, O., \& Roth, G. (2011). Principals' leadership and teachers' motivation: Selfdetermination theory analysis. Journal of Educational Administration, 49(3), 256-275.

Gagné, M., \& Deci, E. L. (2005). Self-determination theory and work motivation. Journal of Organizational Behavior, 26(4), 331-362.

Green, S. K. (2002). Using an expectancy-value approach to examine teachers' motivational strategies. Teaching and Teacher Education, 18(8), 989-1005.

Group: Sarawak incest and teen rape cases alarming. (2017, October 1). The Star Online. Retrieved from https://www.thestar.com.my/news/nation/2017/10/01/groupswak-incest-and-teen-rape-cases-alarming/.

Hammersley, M., \& Atkinson, P. (2007). Ethnography: Principles in practice. Routledge.

Henderson, K., \& Tilbury, D. (2004). Whole-school approaches to sustainability: An international review of sustainable school programs. Australian Research Institute in Education for Sustainability: Australian Government.

Hui, E. K. (2000). Guidance as a whole school approach in Hong Kong: From remediation to student development. International Journal for the Advancement of Counselling, 22(1), 69-82.

Hui, E. K. (2002). A whole-school approach to guidance: Hong Kong teachers' perceptions. British Journal of Guidance and Counselling, 30(1), 63-80.

Hui, E. K., \& Lo, R. C. (1997). A whole-school approach to guidance: A Hong Kong experience. Pastoral Care in Education, 15(2), 22-28.

Ibrahim, I.N. (2018, June 7). Teachers' paperworks reduced, says Maszlee. Malaymail. Retrieved from https://www.malaymail.com/s/1639580/teachers-paperwork-reducedsays-maszlee.

Jacobs, K., \& Struyf, E. (2015). A first step toward a comprehensive model of integrated socio-emotional guidance: Investigating the effect of teachers' task perception and a supportive network at school. The Journal of Educational Research, 108(2), 95-111.

Johari, J., Tan, F. Y., \& Zulkarnain, Z. I. T. (2018). Autonomy, workload, work-life balance and job performance among teachers. International Journal of Educational Management, 32(1), 107-120.

Kasmini, K., Kyaw, O., Krishnaswamy, S., Ramli, H., \& Hassan, S. (1993). A prevalence survey of mental disorders among children in a rural Malaysian village. Acta Psychiatrica Scandinavica, 87(4), 253-257. 
Kidger, J., Gunnell, D., Biddle, L., Campbell, R., \& Donovan, J. (2010). Part and parcel of teaching? Secondary school staff's views on supporting student emotional health and well-being. British Educational Research Journal, 36(6), 919-935.

Lam, S. K., \& Hui, E. K. (2010). Factors affecting the involvement of teachers in guidance and counselling as a whole-school approach. British Journal of Guidance \& Counselling, 38(2), 219-234.

Lapan, R. T. (2001). Results-based comprehensive guidance and counseling programs: A framework for planning and evaluation. Journal of Professional School Counseling, 4, 289-299.

Maehr, M. L., \& Zusho, A. (2009). Achievement goal theory: The past, present, and future. In K. R. Wenzel, \& A. Wigfield (Eds.), Educational psychology handbook series. Handbook of motivation at school (p. 77-104). Routledge/Taylor \& Francis Group.

Manyin: Education ecosystem in rural schools still far behind. (2018, July 18). BorneoPost Online. Retrieved from http://www.theborneopost.com/2018/07/18/manyineducation-ecosystem-in-rural-schools-still-far-behind/.

Martin, J. J., \& Kulinna, P. H. (2004). Self-efficacy theory and the theory of planned behavior: Teaching physically active physical education classes. Research Quarterly for Exercise and Sport, 75(3), 288-297.

McCrae, R. R., \& Costa, P. T., Jr. (1999). A five-factor theory of personality. In L. A. Pervin \& O. P. John (Eds.), Handbook of personality: Theory and research (p. 139153). Guilford Press.

Miller, I. W., \& Norman, W. H. (1979). Learned helplessness in humans: A review and attribution-theory model. Psychological Bulletin, 86(1), 93.

Ministry of Education, Malaysia. (2018, December 2). National Education Philosophy [Official website]. Retrieved from https://www.moe.gov.my/index.php/en/dasar/falsafah-pendidikan-kebangsaan.

Misoi, S. A. (2008). Workload of form teachers in secondary schools in Bau District. Faculty of Cognitive Sciences and Human Development, Universiti Malaysia Sarawak.

Mukundan, J., Rezvani, S. A., \& Zare, P. (2016). Burnout among primary and secondary school teachers of English subject in Malaysia. Modern Journal of Language Teaching Methods, 6(6), 354-364.

Neves de Jesus, S., \& Lens, W. (2005). An integrated model for the study of teacher motivation. Applied Psychology, 54(1), 119-134.

Nga, J. K. H., \& Shamuganathan, G. (2010). The influence of personality traits and demographic factors on social entrepreneurship start up intentions. Journal of Business Ethics, 95(2), 259-282. 
Nowell, L. S., Norris, J. M., White, D. E., \& Moules, N. J. (2017). Thematic analysis: Striving to meet the trustworthiness criteria. International Journal of Qualitative Methods, 16(1), 1-13.

Park, A., Conway, M., \& Chen, A. T. (2018). Examining thematic similarity, difference, and membership in three online mental health communities from reddit: a text mining and visualization approach. Computers in Human Behavior, 78, 98-112.

Rashid, R. A., Abdul Rahman, S. B., \& Yunus, K. (2017). Reforms in the policy of English language teaching in Malaysia. Policy Futures in Education, 15(1), 100-112.

Rep tells teachers to act as career counsellor in rural schools. (2013, June 17). BorneoPost Online. Retrieved from http://www.theborneopost.com/2013/06/17/reptells-teachers-to-act-as-career-counsellor-in-rural-schools/.

Richardson, P. W., Karabenick, S. A., \& Watt, H. M. (Eds.). (2014). Teacher motivation: Theory and practice. Routledge.

Roslan, N. A., Ho, J. A., Ng, S., \& Sambasivan, M. (2015). Job demands \& job resources: Predicting burnout and work engagement among teachers. International Proceedings of Economics Development and Research, 84, 138-145.

Roth, G. (2014). Antecedents and outcomes of teachers' autonomous motivation: a selfdetermination theory analysis. In P. W. Richardson, S. A. Karabenick, \& H. M. G. Watt (Eds.), Teacher motivation (pp. 58-73). New York: Routledge.

Sarawak Government. (2018, November 30). Sarawak Administrative Division and Districts [Official website]. $\quad$ Retrieved from https://www.sarawak.gov.my/web/home/article_view/358/298/.

Sellen, P. (2016). Teacher workload and professional development in England's secondary schools: Insights from TALIS. Education Policy Institute.

Shafie, S., Kadir, S. A., \& Asimiran, S. (2017). Workload of technical secondary school teachers: management and administration's perceptions. MOJEM: Malaysian Online Journal of Educational Management, 2(4), 21-35.

Shah, A. (2018, September 18). [Exclusive] "Reduce teachers' workload”. New Straits Times. Retrieved from https://www.nst.com.my/news/exclusive/2018/09/412392/exclusive-reduce-teachersworkload.

Simbula, S. (2010). Daily fluctuations in teachers' well-being: A diary study using the Job Demands-Resources model. Anxiety, Stress, \& Coping, 23(5), 563-584.

Srivastava, P., \& Hopwood, N. (2009). A practical iterative framework for qualitative data analysis. International journal of qualitative methods, 8(1), 76-84.

STU welcomes timely setting up of special committee to tackle teachers' shortage woes. (2018, September 14). BorneoPost Online. Retrieved from 
http://www.theborneopost.com/2018/09/14/stu-welcomes-timely-setting-up-of-specialcommittee-to-tackle-teachers-shortage-woes/.

Teachers: Teaching no longer a passion but a but a burden today. (2018, October 12). The Star Online. Retrieved from https://www.thestar.com.my/news/nation/2018/10/12/teachers-teaching-no-longer-apassion-but-a-burden-today/.

Teachers' woes in rural Sarawak. (2010, January 3). BorneoPost Online. Retrieved from http://www.theborneopost.com/2010/01/03/teachers\%E2\%80\%99-woes-in-ruralsarawak/.

Thomson, M. M., \& Palermo, C. J. (2018). Using an expectancy-value model to understand teaching motivation among nontraditional preservice teachers: A phenomenological study approach. Action in Teacher Education, 40(2), 151-168.

Turner, J. E., Waugh, R. M., Summers, J. J., \& Grove, C. M. (2009). Implementing high-quality educational reform efforts: An interpersonal circumplex model bridging social and personal aspects of teachers' motivation. In P. A: Schutz, \& M. Zembylas (Eds.), Advances in teacher emotion research (pp. 253-271). Boston, MA: Springer.

Wang, H., Hall, N. C., Goetz, T., \& Frenzel, A. C. (2017). Teachers' goal orientations: Effects on classroom goal structures and emotions. British Journal of Educational Psychology, 87(1), 90-107.

Weinten, W. (2007). Psychology: Themes and variations. California: Wadsworth.

Wigfield, A., \& Eccles, J. S. (2000). Expectancy-value theory of achievement motivation. Contemporary Educational Psychology, 25(1), 68-81.

World Health Organization. (2003). Creating an environment for emotional and social well-being: an important responsibility of a health promoting and child-friendly school. Geneva: World Health Organization [Online document]. Retrieved from http://apps.who.int/iris/handle/10665/42819.

Yuen, M., Chan, R. M. C., Lau, P. S. Y., Gysbers, N. C., \& Shea, P. M. K. (2007). Comprehensive guidance and counselling programmes in the primary schools of Hong Kong: Teachers' perceptions and involvement. Pastoral Care, 25, 17-24. 